\title{
Okul Öncesi Öğretmenlerinin Çocukları Değerlendirmedeki Yeterlilik Düzeyleri ve Kullandıkları Araçlar
}

\author{
Nesrin IŞIKOĞLU ERDOĞAN', Selcen AYDOĞAN², Serap EFE KENDÜZLER³, \\ Ezgi DÜLGER CEYLAN ${ }^{4}$, Ayşe AYDIN5 , Hızır DiNLER ${ }^{6}$
}

\begin{abstract}
Öz: Bu çalışmanın amacı, okul öncesi öğretmenlerinin çocukların gelişimini değerlendirmede kullandıkları araçları ve öğretmenlerin değerlendirme yeterlilik düzeyini belirlemektir. Bu çalışmada nicel ve nitel verilerin toplandığı karma araştırma deseni kullanılmıştır. Araştırmanın nicel boyutu, Türkiye'nin farklı bölgelerinde çalışan 518 okul öncesi öğretmenini kapsamaktadır. Nicel verilerin toplanmasında öğretmenlere Çocukların Tanınması ve Değerlendirilmesi Bilgi Testi uygulanmıştır. Araştırmanın nitel boyutuna toplam 10 gönüllü öğretmen katılmıştır. Nitel veriler yarı yapılandırılmış görüşmeler yoluyla toplanmıştır. Araştırmanın nicel bulguları, öğretmenlerin bilgi düzeylerinin ve değerlendirmelerinin orta düzeyde yoğunlaştığını göstermektedir. Nitel verilerden elde edilen bulgular üç temada toplanmıştır; 1) Neden değerlendiriyorum? 2) Neyi değerlendiriyorum? 3) Nasıl değerlendiriyor ve belgelendiriyorum? Öğretmenler, çocukların gelişimsel alanlarda ne kadar ilerlediklerini tespit etmek amacıyla, gözlem ve portfolyo yöntemlerini kullanarak ilgili kişilerle paylaşmak için değerlendirme yaptıklarını ifade etmişlerdir.
\end{abstract}

Anahtar Sözcükler: Değerlendirme, Değerlendirme Araçları, Okul Öncesi, Öğretmen Yeterlilikleri

\section{Preschool Teachers' Competence Levels and Tools Used in Child Assessment}

\begin{abstract}
This research aims to determine the tools used by preschool teachers in assessing children's development and the teachers' level of competency in child assessment. In this study, combinations of quantitative and qualitative methods were employed. Five hundred eighteen preschool teachers working across Turkey were the participants of the quantitative dimension of the research. For collecting quantitative data, the Evaluation and Assessment Knowledge Test was used. A total of 10 volunteer teachers participated in the qualitative dimension of the research. Qualitative data were collected through semi-structured interviews. Quantitative findings of the study suggested that teachers' knowledge level and competence levels about child assessment were at moderate levels. Qualitative results were revealed three themes; 1) Why am I assessing? 2) What am I assessing? 3) How do I assess and document? Teachers stated that in order to determine how far children progressed in developmental domains, they used observation and portfolio techniques to share the results with relevant people.
\end{abstract}

Keywords: Assessment, Assessment and Evaluation Tools, Early Childhood, Teacher Competency

1 Pamukkale Üniversitesi, Eğitim Fakültesi, Okul Öncesi Eğitimi, Denizli, Türkiye, e-posta: nisikoglu@pau.edu.tr, ORCID: https://orcid.org/0000-0001-7010-302X

2 Adnan Menderes Üniversitesi, Eğitim Fakültesi, Okul Öncesi Eğitimi, Aydın, Türkiye, e-posta: selcenaydogan@gmail.com, ORCID: https://orcid.org/0000-0002-5171-3233

${ }^{3}$ Milli Eğitim Bakanlığı, Burdur, Türkiye, e-posta: serapefekenduzler@gmail.com, ORCID: https://orcid.org/0000-0002-9584-3742

4 Pamukkale Üniversitesi, Okul Öncesi Eğitimi, Denizli, Türkiye, e-posta: ezgidulger90@gmail.com, ORCID: https://orcid.org/0000-0002-2107-9948

5 Mehmet Akif Ersoy Üniversitesi, Bucak Hikmet Tolunay MYO, Çocuk Gelişimi, Burdur, Türkiye, e-posta: aaydin@mehmetakif.edu.tr, ORCID: https://orcid.org/0000-0001-9657-8082

6 Kilis 7 Aralık Üniversitesi, Muallim Rıfat Eğitim Fakültesi, Kilis, Türkiye, e-posta: hizirdinler@kilis.edu.tr, ORCID: https://orcid.org/0000-0003-3144-6649 
Okul öncesi öğretmenlerinin çocukların bilişsel, psikomotor, dil, sosyal ve duygusal gelişim düzeylerinin eğitim sürecinde takip edilerek çocukları tanıma ve değerlendirme tekniklerini kullanması, eğitimlerin önemli bir parçasıdır. Değerlendirme sayesinde çocuğun öğrenme ve gelişim düzeyi ile ilgili gerekli bilgiler toplanarak eğitimin belirlenen hedeflerine ne kadar ulaşıldığı ortaya koyulabilmektedir. Böylece aksaklıklara zamanında gerekli müdahaleler yapılarak, gelişimde kritik olan bu dönemin daha sağlıklı geçirilmesi sağlanabilir (Bredekamp ve Rosegrant, 1992).

Çocukların sergiledikleri davranışları anlamlandırabilmek, hedef davranışları saptayabilmek ve bu hedeflere ulaşmayı sağlayan öğretim stratejilerini uygulayabilmek için okul öncesi öğretmenlerinin, çocukların gelişimsel özelliklerini çok iyi bilmeleri gerekir (Howard, Williams ve Lepper, 2010). Çocukların her birinin ilgisi, kendine özgü gelişim düzeyi gereksinimleri, kapasitesi, yetenekleri, güçlü ve zayıf yönleri, sorunları, istekleri, yetiştiği çevrenin geliştirici ve engelleyici etkileri, kişisel ve sosyal uyum düzeyleri gibi daha birçok özellikleri birbirinden farklıdır. Bunlar çocuğun tanınması açısından bilinmesi gereken özelliklerdir. Çocuklar bu yönlerden yeterli düzeyde tanındığında güçlü yönleri ve desteğe ihtiyaç duydukları noktalar daha kolay tespit edilebilir (Aktepe, 2005; Tagay, 2016). Eğitim programının esneklik ilkesi içerisinde, eğitim ve öğretimi çocukların bu farklılıklarına göre düzenleyebilmek için, okul öncesi öğretmenlerinin çocukları tanıma ve değerlendirmeye önem vermesi gerekmektedir.

Değerlendirme en genel anlamda "çeşitli şekillerde belgelerden faydalanılarak çocuklar hakkında bilgi toplama ve elde edilen bilgileri düzenleyip yorumlama süreci" olarak ifade edilmiştir (McAfee, Leong ve Bodrova, 2004). Benzer şekilde, "çocuğun gelişimini tanımlamak için toplanan verilerden çıkarımda ve yorumda bulunarak çocukla ya da eğitimiyle ilgili karar verme süreci" olarak değerlendirmenin hem çocuk hem de eğitimle ilgili boyutları vurgulanmıştır (Iş̧koğlu Erdoğan ve Canbeldek, 2017). Ayrıca değerlendirme, eğitim programının eğitsel amaçlarına ne derecede ulaşıldığının bir göstergesidir. Dolayısıyla değerlendirme, eğitimin başlangıcında, süreç boyunca ve sonunda belli bir düzen ve zaman içinde gerçekleştirilir (Karaağaçlı, 2002). Değerlendirme Milli Eğitim Bakanlığı (MEB) Okul Öncesi Eğitimi Programında önemli bir yer tutmaktadır. Programda değerlendirme, çocuğun bütün gelişim alanlarının ayrıntılı bir şekilde ve bütün boyutları ile gözlenmesi, gözlemlerin rapora dönüştürülmesi, hazırlanan ve uygulanan planların bütünsel bir şekilde değerlendirilmesi ve öğretmenin kendini değerlendirmesi olarak farklı şekillerde ele alınmıştır (MEB, 2013).

Değerlendirme, çocukların gelişim düzeyleri, eğitim programının amaçlarına ulaşma düzeyi, öğretmeninin kendi performansı gibi farklı boyutları çeşitli değerlendirme araç ve teknikleri kullanılarak ele alır (Önder, 2016). Okul öncesi öğretmenleri de etkili değerlendirme yapmak için farklı değerlendirme araç ve tekniklerinden yararlanırlar. Bunlar, gelişimi izlemeye yardımcı, farklı özellikleri ölçen standart testler kullanma, kontrol listeleri, gözlem formları doldurma, kendi sınıf ortamları üzerine rapor tutma ve uygulamalarda bulunmayı içerir (McAfee ve Leong, 2012).

Çocukların gelişim ve öğrenmelerini değerlendirmek için okul öncesi öğretmenleri formal, informal ve alternatif olmak üzere üç temel değerlendirme yaklaşımından yararlanırlar (Işıkoğlu Erdoğan ve Canbeldek, 2017). Formal değerlendirme, daha çok sonuç odaklı ve standart araçlar kullanılarak yapılan değerlendirmedir (Gullo, 2005). İşlevlerine göre formal değerlendirme araçları; "gelişimsel tarama testleri, tanılayıcı testler, hazır bulunuşluk testleri, başarı ve yetenek testleri" olmak üzere beş temel grupta ele alınmaktadır (Bredekamp, 2015). İnformal değerlendirme ise görüşme, gözlem, derecelendirme ölçekleri, rubrik ve etkinlik örnekleri gibi gelişim ve öğrenme süreçlerini ortaya koyan teknikler kullanılarak yapılan değerlendirmedir (McAfee ve Leong, 2012). Formal değerlendirmeden farklı olarak informal değerlendirmede çocuğun performansı, sinıfta doğal ortamda yapılır. Son olarak okul öncesi öğretmenleri çocukların sürece etkin katıldıkları, doğal ortamda yapılan oyun veya program temelli, dinamik ve portfolyo gibi farklı araçlar kullanılarak yapılan alternatif değerlendirme yaklaşımını kullanılırlar. Bu değerlendirme yaklaşımı, gelişim ve öğrenme sürecini hem sonuç hem de süreç olarak ortaya koyar (Riley, Miller ve Sorenson, 2016).

Alanyazında çocukları tanıma ve değerlendirme ile ilgili okul öncesi öğretmenlerinin görüşleri ve sınıf içi uygulamalarını inceleyen betimsel araştırmalar yer almaktadır. Bir araştırmada öğretmenlerin görüşlerinin 
okul öncesi eğitimde süreç odaklı değerlendirme yapılması yönünde olmasına rağmen (Turupçu, 2014) başka bir araştırmada incelenen dokümanlar ve görüşmelerden elde edilen verilerin sonucunda, öğretmenlerin süreç odaklı değerlendirme yapmadıkları saptanmıştır (Burgazlı Osanmaz ve Akman, 2018). 145 okul öncesi öğretmeninden anket yoluyla bilgilerin toplandığı benzer bir araştırmada, öğretmenlerin tanıma tekniklerini uygulama ve değerlendirmede kendilerini yeterli gördüğü, en çok gözlem ve görüşme tekniklerini uyguladıkları ve gelişimi ölçen testler kısmını boş bırakarak cevap vermedikleri, verilen cevapların da yetersiz olduğu tespit edilmiştir (Taner, 2005). Yine, okul öncesinde görev yapan toplam 34 öğretmenin görüşleri alınarak yapılan araştırma sonucunda, öğretmenlerin genellikle gözlem ve görüşme tekniklerini kullandıkları belirtilmiş, ayrıca değerlendirme sürecinde toplanan bilgileri bir ilerleme raporu yazmak, ebeveynleri bilgilendirmek ve etkinlik planlamak için kullandıkları; ancak bazı öğretmenlerin bunları hiç kullanmadığı ifade edilmiştir (Yılmaz Topuz ve Erbil Kaya, 2016).

Alanyazında okul öncesi öğretmenlerinin çocukların gelişimlerini değerlendirmede kullandıkları araçların incelendiği birçok çalışmaya rastlanmıştır (Brown ve Rolfe, 2005; Kaya, 2018; Kwi-Ok ve Jung-In, 2011; Pyle ve DeLuca, 2017; Yılmaz Topuz ve Erbil Kaya, 2016). Erken çocukluk eğitimcileri ile yapılan görüşmeler ve dokümanların analizine göre, değerlendirmede en sık kullanılan formların gözlem, derecelendirme ölçekleri ve çocuğun gelişimi üzerine yapılan kontrol listelerinden oluştuğu belirlenmiştir (Kwi-Ok ve Jung-In, 2011). Brown ve Rolfe (2005) çalışmaya katılan 20 erken çocukluk dönemi eğitmeni ile yaptığı araştırma sonucunda, çoğunun informal değerlendirme araçlarını kullandığını fakat sadece \%10'unun formal değerlendirme araçlarına yer verdiği sonucuna ulaşmıştır. Öğretmenlerin alternatif değerlendirme araçlarını kullanmaları ile ilgili yapılan bir araştırmada ise çocukları oyun yoluyla tanıma ve değerlendirmede somut bilgi edinmek için oyun temelli değerlendirmeden yararlandıkları; eğitim planları çerçevesinde program temelli bir yaklaşımla yürüttükleri ve programla ilgili çeşitli biçimlerde değerlendirme yaptıkları tespit edilmiştir. Ancak, programın amaçlarının/sonuçlarının, gelişmeyi değerlendirmek için program tabanlı yaklaşımı etkin bir şekilde kullanmadıkları belirlenmiştir (Kaya, 2018). Benzer şekilde öğretmenlerin okul öncesi eğitiminde oyun temelli değerlendirme yaklaşımına ilişkin bilgilerini arttırmada, analiz etme ve kullanma konusundaki bilgi ve becerilerinin desteklenmesi gerektiği ifade edilmiştir (Pyle ve DeLuca, 2017). Alanyazında okul öncesi öğretmenlerinin değerlendirme araçlarını kullanmasının, çocuğun öğrenme sürecinde kazandıkları davranışları ve düzeylerini belirleyerek takip edebilmesi böylece çocuğun gelişim düzeylerine yönelik öğrenme fırsatlarını sunabilmesi açısından gerekli olduğu vurgulanmıştır. Bu sebeple, öğretmenlerin çocukların gelişimlerini değerlendirmede kullandıkları araçlar ve değerlendirmedeki yeterlilik düzeylerinin incelenmesinin yararlı olacaktır. Yapılan araştırmalar incelendiğinde, çoğunlukla nicel veya nitel yöntemlerin kullanıldığı görülmektedir. Bu araştırmada, öğretmenlerin bilgi düzeylerinin bilgi testi ile ölçülmesi, öğretmenlerle derinlemesine görüşmelerin yapılması ve çocukları tanıma ve değerlendirmede kullandıkları yöntemlerin dokümanlarının toplanması ile üçgenleme yönteminin kullanılması çalışmanın üstün bir yönüdür. Ayrıca alan yazın incelendiğinde öğretmenlerin çocukları değerlendirme konusundaki yeterlilik düzeylerinin bilgi testi ile ölçüldügü bir araştırmaya rastlanmamıştır. Bu araştırmada Türkiye'nin birçok bölgesinden okul öncesi öğretmenine ulaşılmıştır. Bu bakımından yapılan araştırmanın alanyazına önemli katkılar sunacaktır. Bu sebeple, okul öncesi öğretmenlerinin çocukların gelişimlerini değerlendirmede kullandıkları araçlar ve değerlendirmedeki yeterlilik düzeylerinin belirlenmesi bu makalenin amacını oluşturmaktadır.

\section{Yöntem}

Bu araştırmada nicel ve nitel yöntemlerin bir arada kullanıldığı karma araştırma deseni seçilmiştir. Karma yöntem araştırması, araştırmacının bir çalışmada hem nitel hem de nicel yaklaşımları kullanarak veriler topladığı ve analiz ettiği, bulguları birleştirdiği ve sonuçlar çıkardığı araştırma olarak tanımlanmıştır (Tashakkori ve Creswell, 2007). Sıralı açıklayıcı desene uygun olarak öncelikle nicel veri toplama ve veri analizi, buradan elde edilen bulgular ışığında nitel veri toplama ve veri analizi gerçekleștirilmiștir (Creswell, 2003). Karma yöntem yaklaşımına uygun olarak hazırlanan bu araştırmanın nicel boyutunda tarama modeli, nitel boyutunda ise durum çalışması modeli kullanılmıştır. Genel tarama modelinde, çok sayıda elemandan oluşan bir evrende, evren hakkında genel bir yargıya varmak için evrenin tümü ya da ondan alınacak bir grup 
örnek ya da örneklem üzerinde tarama yapılmaktadır (Karasar, 2011). Creswell'e (2009) göre durum çalışması, araştırmacının zaman içerisinde sınırlandırılmış bir veya birkaç durumu çoklu kaynakları içeren veri toplama araçları (gözlemler, görüşmeler, görsel-işitseller, dokümanlar, raporlar) ile derinlemesine incelediği, durumların ve duruma bağlı temaların tanımlandığı nitel bir araştırma yaklaşımıdır.

\section{Çalışma Grubu}

Araştırmanın nicel boyutuna Türkiye genelinde devlet okulları ve özel okullarda görev yapmakta olan 518 okul öncesi öğretmeni katılmıştır. Çocukları Tanıma ve Değerlendirme Bilgi Testi (ÇTDBT) internet üzerinden veya kâğıt kalem ile doldurulmak üzere iki formda hazırlanmıştır. İnternet üzerinden uygulanan ÇTDBT, sosyal medya platformlarından üç ay boyunca duyurulmuş ve gönüllü olan 377 okul öncesi öğretmeni bu testi doldurarak çalışmaya katılmışlardır. Araştırmacıların ikamet ettikleri illerde ise bizzat okullara ÇTDBT dağıtılmış ve 141 gönüllü okul öncesi öğretmeninin testi doldurması sonrası tekrar toplanmıştır. Test sonrası öğretmenlere görüşme yapılacağı ve kendileri ile görüşme yapılmasını istiyorlarsa iletişim bilgilerinin verilmesi hususunda bilgi verilmiştir. Öğretmenlere ait demografik bilgiler aşağıda verilmiştir.

Tablo 1

Öğretmenlere ait demografik bilgiler

\begin{tabular}{|c|c|c|c|c|c|}
\hline & & \multicolumn{2}{|c|}{ Nicel verilerin elde edildiği grup } & \multicolumn{2}{|c|}{ Nitel verilerin elde edildiği grup } \\
\hline & & $\mathbf{N}$ & $\%$ & $\mathbf{N}$ & $\%$ \\
\hline \multirow[t]{2}{*}{ Cinsiyet } & Kadın & 395 & 76.26 & 9 & 90 \\
\hline & Erkek & 123 & 23.75 & 1 & 10 \\
\hline \multirow[t]{4}{*}{ Yaş } & $23-30$ & 212 & 40.93 & 5 & 50 \\
\hline & $30-35$ & 152 & 29.34 & 4 & 40 \\
\hline & $35-40$ & 102 & 19.69 & 1 & 10 \\
\hline & $40+$ & 52 & 10.04 & - & - \\
\hline \multirow[t]{2}{*}{ Öğrenim Durumu } & Lisans & 505 & 97.49 & 10 & 100 \\
\hline & Yüksek lisans & 13 & 2.51 & - & \\
\hline \multirow[t]{2}{*}{ Çalıştığı kurum türü } & Resmi & 355 & 68.53 & 8 & 80 \\
\hline & Özel & 163 & 31.47 & 2 & 20 \\
\hline
\end{tabular}

Tablo 1' de çalışmanın nicel boyutuna katılan öğretmenlerin \%76.26 kadın, \%40'nın 25-30 yaş aralığında, \%97.49'unun lisans mezunu, \%68.53'ünün resmi okullarda görev yaptığı görülmektedir. Çalışmanın nitel verileri için ÇTDBT değerlendirildikten sonra kritik durum örnekleme tekniğine göre bu testten en düşük ve en yüksek puan alan, ayrıca nitel görüşme yapmayı kabul eden 10 öğretmen seçilmiştir. Çalışmanın nitel boyutuna katılan öğretmenlerin \%90'nın kadın ve okul öncesi öğretmenliği mezunu olduğu, \%50'sinin 23-30 yaş aralığında olduğu, \%80'inin resmi devlet okullarında çalıştığı görülmektedir.

\section{Veri Toplama Araçları ve Etik İlkeler}

Araştırma kapsamında nitel ve nicel veri toplama araçları bir arada kullanılmıştır. Nicel veriler için ÇTDBT uygulanmış, daha sonra düşük ve yüksek puana sahip gönüllü öğretmenler ile yarı yapılandırılmış görüşmeler yapılmıştır. Görüşmeler esnasında ise öğretmenlerin çocukların gelişimlerini değerlendirirken kullandıkları araçlara ilişkin örnekler toplanmıştır. Öğretmenlerin bilgi düzeylerinin ÇTDBT ile ölçmesi, derinlemesine görüşmelerin yapılması ve dokümanların toplanması ile araştırmada üçgenleme kullanılmıştır. Üçgenleme, bilgilerin başka kaynaklardan doğrulanması veya genişletilmesidir. Görüşmenin yanında halihazırda bulunan dokümanların toplanarak araştırma tasarımının bir parçası şeklinde dahil edilmesi araştırmaya avantaj sağlamaktadır. Verilerin birçok kaynaktan gelerek üçgenleştirilmesi, bu bilgilere dayanarak bulguların rapor edilmesinde güveni artırmaktadır (Hatch, 2002).

Araştırmanın verileri toplanmadan önce Adnan Menderes Üniversitesi Eğitim Araştırmaları Etik Kurulundan, İl Milli Eğitim Müdürlüğünden, okul yöneticileri ve katılımcılardan izinler alınmıştır. Çalışmaya katılmak için gönüllü olan katılımcılara, çalışmanın amacı ve onam formuna ilişkin esaslar ayrıntılı olarak açıklanmıştır. Görüşmelerin başında veri kaybını önlemek için görüşmelerin ses kayıt cihazı ile kaydedilmesine ilişkin izinler alınmıştır. Bütün katılımcılar izin vermişlerdir. Öğretmenlerle okul dışında sessiz bir ortamda ve yüz yüze görüşmeler yapılmıştır. Katılımcıların kimliğini gizli tutmak için okul isimleri 
Okul Öncesi Öğretmenlerinin Çocukları Değerlendirmedeki ...

kullanılmamış ve katılımcılara kod isimler verilmiştir. Ses kayıtlarına ve verilere sadece araştırma grubunun erişim olacağı garanti edilmiştir.

\section{Nicel Veri Toplama Aracı}

\section{ÇTDBT'nin geliştirilme süreci: Hazırlanması ve geçerlik çalışması.}

ÇTDBT araştırmacılar tarafından öğretmenlerin çocukların gelişimlerini ölçme ve değerlendirmedeki yeterliliklerini ölçmek amacıyla geliştirilmiştir. İlk olarak testin hazırlanabilmesi amacıyla, Bloom'un (1979) eğitim hedefleri ile ilgili aşamalı sınıflaması dikkate alınarak bir belirtke tablosu hazırlanmıştır. Oluşturulan belirtke tablosu yardımı ile öncelikle bilgi, kavrama ve uygulama düzeyinde olmak üzere 25 maddeden oluşan çocukları tanıma ve değerlendirmeye yönelik çoktan seçmeli 4 seçenekli bir soru havuzu oluşturulmuştur. Daha sonra soru maddelerine yönelik Okul Öncesi Eğitimi (5), Ölçme ve Değerlendirme (1) ve Psikolojik Danışmanlık ve Rehberlik (2) olmak üzere toplam 7 akademisyenden uzman görüşü alınmış ve gerekli değişiklikler yapılmıştır. Testin geçerlik ve güvenirlik çalışmaları dördüncü sınıfa devam eden 98 okul öncesi öğretmen adayı ile gerçekleştirilmiştir. Uygulama sonrasında ölçme aracının güvenilirliğini saptamak amacıyla madde analizleri yapılmıştır. Ayrıca her maddenin madde güçlük ve ayırıcılık indeksi hesaplanmiştır (Tablo 2).

Tablo 2

(ÇTDBT)'nin pj(madde güçlük indeksi), ss (standart sapma), rpbi (Çiftserili nokta indeksi) ve rj (madde ayırıcllk indeksi) değerleri

\begin{tabular}{ccccc}
\hline Madde No & Pj & ss & rpbi & rj \\
\hline S3 & 0,81 & 0,40 & 0,40 & 0,41 \\
S4 & 0,53 & 0,50 & 0,39 & 0,48 \\
S5 & 0,41 & 0,49 & 0,48 & 0,63 \\
S6 & 0,56 & 0,50 & 0,34 & 0,41 \\
S7 & 0,38 & 0,43 & 0,67 \\
S8 & 0,49 & 0,62 & 0,74 \\
S10 & 0,50 & 0,45 & 0,44 \\
S12 & 0,47 & 0,54 & 0,56 \\
S13 & 0,63 & 0,55 & 0,63 \\
S14 & 0,68 & 0,47 & 0,38 & 0,44 \\
S15 & 0,64 & 0,50 & 0,64 & 0,67 \\
S19 & 0,50 & 0,44 & 0,46 & 0,37 \\
S20 & 0,73 & 0,50 & 0,52 \\
S22 & 0,40 & 0,48 & 0,52 \\
S23 & 0,81 & 0,47 & 0,44 & 0,63 \\
\hline
\end{tabular}

Madde ayırt edicilik indeksi, maddelerin ölçülen özellikleri ile ilgili olarak bireyleri ne derece ayırt ettiğini gösterir ve -1 ile +1 arasında değişebilir. Madde ayırt edicilik indeksi bütün katılımcıların puanlarının en yüksekten en düşüğe doğru sıralanarak, bu sıralamada katılımcıların yukarıdan aşağıya doğru ilk \%27'si üst grup ve aşağıdan yukarı ilk \%27'si de alt grup olarak belirlenip, grupların farkının alt grup sayısına bölünmesi ile hesaplanabilir (Büyüköztürk, Çakmak, Akgün, Karadeniz ve Demirel, 2016). Bu bağlamda öncelikle testte yer alan maddelerin ayırt edicilik düzeylerini incelemek üzere 98 öğretmen adayının sonuçları en yüksekten en düşüğe doğru sıralanmış ve \%27'lik alt ve üst gruplar belirlenmiştir. Üst ve alt grup puan farkı alt grup sayısına bölünerek her bir maddenin madde ayırt edicilik indeksi hesaplanmıştır. 1, 2, 9, 11, 16, 17, 18, 21,24 ve 25. maddelerin madde ayırıcılık indeksi .20'nin altında olduğu için çıkartılmıştır. Böylece testte 15 adet madde yer almıştır.

Testin iç güvenirliğini ölçmek için Kr-20 (Kuder-Richardson) değeri hesaplanmıştır. Hesaplanan güvenirlik katsayısının .70 ve daha yüksek olması test puanlarının güvenirliği için genel olarak yeterli görülmektedir (Büyüköztürk ve diğerleri, 2016). Yapılan analiz sonucunda ÇTDBT'nin iç güvenirlik katsayısı .76 bulunmuştur. Bu bulgular doğrultusunda, çocukların gelişimlerini ölçme ve değerlendirme düzeylerini ölçmede öğretmenler için hazırlanmış bu testin kullanılabilecek düzeyde bir güvenilirliğe sahip olduğu söylenebilir. 


\section{Nitel Veri Toplama Araçları}

$\mathrm{Bu}$ çalışmada nitel veri toplama aracı olarak yarı-yapılandırılmış görüşme formu kullanılmıştır. Kullanılan yarı-yapılandırılmış görüşme formu üç bölümden oluşmaktadır. Birinci bölümde çocukları tanıma ve değerlendirmenin amacı, önemi, yararlarına yönelik sorular, ikinci bölümünde öğretmenlerin çocukların gelişimlerini değerlendirmede kullandıkları araçlar ve kullanma şekillerine yönelik sorular, üçüncü bölümde ise çocukların gelişimsel süreçlerini nasıl değerlendirdikleri, kimlerle paylaştıkları, eğitim programını ve kendilerini nasıl değerlendirdiklerine ilişkin sorular bulunmaktadır. Ayrıca görüşme formunun son hali verilirken yedi akademisyenin uzman görüşü alınmıştır. Görüşmelerin derinleştirilmesi, verilerin daha kapsamlı elde edilmesi amacı ile görüşmeler üç oturumda tamamlanmıştır (Seidman, 2006). Her bir görüşmenin arası bir hafta olarak belirlenmiştir. Görüşmeler sessiz bir ortamda bireysel olarak yapılmış, yaklaşık olarak her bir görüşme 60 dakika sürmüş ve ses kayıt cihazı ile kaydedilmiştir. Doküman incelenmesi için ise, öğretmenlerin yıl içinde çocukları tanıma ve değerlendirme amacıyla oluşturdukları gözlem kayıtları, portfolyo etkinlik örnekleri gibi dokümanlar görüşmeler esnasında öğretmenlerden istenmiştir. Elde edilen bu dokümanlar görüşme sonrasında analiz edilmiştir. Yüksek yeterlilik düzeyindeki öğretmenlere Asu, Alev, Arzu, Aynur, Aylin şeklinde, düşük yeterlilik düzeydeki öğretmenlere ise Zeynep, Zehra, Züleyha, Zübeyde, Zülal şeklinde kod isimler verilmiştir.

\section{Verilerin Toplanması ve Analizi}

Sıralı açıklayıcı desene uygun olarak planlanan bu araştırmada öncelikle nicel veri toplama ve veri analizi, daha sonra nitel veri toplama ve analizi yapılarak bulgular sunulmuştur. Nicel analizlerle, frekans değerleri kullanılarak öğretmenlerin yeterlilik düzeylerini ortaya çıkarmak amaçlanmıştır. Nitel veriler ise içerik analizi tekniği kullanılarak analiz edilmiştir. İçerik analizi, elde edilen veriler içinde tekrar eden konular, problemler ve kavramların ayrıştırılması, sayılması ve yorumlanması olarak tanımlanır (Denzin ve Lincoln, 1998). Bu çalışmada görüşme notları ve dokümanlar iki aşamada kodlanmıştır. Birinci aşamada, veriler okunarak kendi içinde anlamlı bütün oluşturan bolümler isimlendirilmiş ve tekrar eden bu kodlardan kategoriler oluşturulmuştur (Yıldırım ve Şimşek, 2000). İkinci aşamada, bu kategoriler içerisindeki veriler, öğretmenlerin çocukları değerlendirme yeterlilikleri açısından literatürde yer alan üç başlık dikkate alınarak değerlendirme döngüsüne (Shepard, Kagan ve Wurtz, 1998) göre tekrar kodlanmıştır. Bu aşamalar "Niçin, neyi, nasıl değerlendiriyorum ve belgelendiriyorum?" şeklindedir.

\section{Bulgular}

\section{Nicel Bulgular}

Okul öncesi öğretmenlerin çocukları tanıma ve onların gelişimlerini değerlendirmedeki yeterlilik düzeylerine ilişkin ÇTDBT'den aldıkları sonuçlar Tablo 3'te verilmiştir.

Tablo 3

Öğretmenlerin çocukları tanıma ve değerlendirme bilgi testi puanlarının $f, \%$ ve ss değerleri

\begin{tabular}{|c|c|c|c|c|c|}
\hline Puan aralıkları & & $f$ & $\%$ & $\bar{X}$ & ss \\
\hline \multirow{4}{*}{$\begin{array}{l}\text { Öğretmenlerin } \\
\text { ÇTDBT Yeterlilik Düzeyleri }\end{array}$} & Düşük puan $(0-4,98)$ & 77 & 14,86 & \multirow{4}{*}{6,63} & \multirow{4}{*}{2,49} \\
\hline & Orta düzey puan $(4,99-9,69)$ & 336 & 64,86 & & \\
\hline & Yüksek puan $(9,70-15,00)$ & 105 & 20,27 & & \\
\hline & Toplam & 518 & 100 & & \\
\hline
\end{tabular}

Tablo 3'te öğretmenlerin \%14.86'sının düşük, \%64.86'sının ise orta düzeyde puanlar alırken sadece \%20.27'sinin yüksek düzeyde puan aldığı görülmektedir. Öğretmenlerin çocukları tanıma ve değerlendirme bilgi düzeylerinin \%64.86 ile orta düzeyde yığıldığı görülmektedir. Bu testten alınabilecek en yüksek puanın 15 olduğu düşünüldüğünde öğretmenlerin puan ortalamalarının $\bar{X}=6.63$ olmasından hareketle, çocukları tanıma ve gelişimlerini değerlendirmedeki bilgi düzeylerinin yüksek olmadığı sonucuna ulaşılmaktadır. 
Ayrıca öğretmenlerin bilgi düzeylerine ilişkin almış oldukları puanların, ortalama başarı puanıla arasındaki ilişkiyi ortaya koymak amacıyla eta kare değeri de hesaplanmıştır. Eta kare etki büyüklüğü değerleri .74 olarak bulunmuştur. Hopkins'e (2014) göre korelasyon katsayısının kendisi, bir etki büyüklüğü değeri olarak tanımlamış ve korelasyon katsayıları için etki büyüklüklerinin yorumlanmasında ise $.00-.10$ arası göz ardı edilebilir; .10-.30 arası küçük; .30-.50 arası orta; .50-.70 arası yüksek; .70-.90 arası çok yüksek; .90-1.00 arası ise mükemmel ilişki olarak nitelendirilmiştir. Bu çalışmada düzey değişkenleri için eta kare değerleri, Hopkins'in yukarıdaki sınıflamasına göre çok yüksek bir etkiye işaret etmektedir.

\section{Nitel Bulgular}

Çocukları değerlendirme yeterlik düzeyi yüksek ve düşük olan öğretmenlerle yapılan görüşmelerin içerik analizleri ayrı ayrı değerlendirilerek, karşılaştırmalar yapılmıştır. Katılımcı öğretmenlerden elde edilen bulgular üç tema etrafında toplanmıştır. Bunlar; 1) Niçin değerlendiriyorum? 2) Neyi değerlendiriyorum? 3) Nasıl değerlendiriyorum ve belgeliyorum? dur.

\section{1) Çocukları neden değerlendiriyorum?}

Yeterlilik düzeyi yüksek olan öğretmenlerin tamamı, "çocukların gelişimsel sürecini izlemek”, "iyi bir eğitim planı hazırlamada yol göstermek", "özel ihtiyacı olan çocukları belirlemek" ve "ilgililerle iletişim kurarken rapor sunmak" amacıyla değerlendirme yaptıkları saptanmıştır. Buna ilave öğretmenler Asu, Aynur ve Arzu "çocukların kendilerini tanımalarına fırsat vermek" amacıyla da değerlendirme yaptığını eklemiştir. Örneğin, Asu "Çocukların güçlü ve zayıf yönlerini bulma, çocuğun kendini keşfetmesini sağlama", Aynur "Çocukların kendilerini tanımaları, kendilerinin farkında olmaları önemlidir. Bu sebepten çocukları değerlendiriyorum." ve Arzu "Çocuk okulda kendi kendine yetebilmeli. Kendi problemlerini çözebilmeli. Çocuklarımı değerlendirirken buna çok önem veriyorum." ifadeleriyle çocukların kendilerini tanımasının önemli olduğunu açıklamışlardır.

Diğer yandan Aylin, "Desteklenmeye ihtiyacı olan çocuklarım var onları biraz daha cesaretlendiriyorum.... iyiyi doğruyu tam olarak ayırt edemeyen çocuklarım var. Bunları görerek aileye yardımcı olmamızı sağlıyor. Çocuğun davranışını olumlu yönde değiştirmemizi sağlıyor. Çocuğu ne yönde desteklememiz gerektiğini anlamamızı sağlıyor." ifadesiyle özel ihtiyaçları olan çocukların belirlenmesi ve aileye bilgi verirken kanıt olarak sunmada değerlendirme araçlarını kullandığını belirtmiştir. Ayrıca Ahu "Bazı öğrencilerimizin gelişimsel problemleri olabiliyor. Bu problemleri tespit edebilmek, gerekli durumlarda okulumuzdaki rehber öğretmenlerle paylaşmak için de değerlendirmeler yapıyorum. Bazen RAM'a gitmesi gerekebiliyor." ifadesiyle ile psikolojik danışman ve rehber öğretmen ile iletişim kurmak ve Aylin'in "Eğer destek alması gerekiyorsa özel eğitim öğretmenleri ile işbirliğinde çalışmak için de değerlendirme yapmak gerekiyor." ifadesinden ise özel gereksinimli çocukların mevcut durumlarını ve ilerlemelerini özel eğitim öğretmeni ile paylaşmak amacıyla da değerlendirme yaptıkları anlaşılmaktadır.

Bunun yanı sıra öğretmenler çocukların öz bakım, sosyal ve duygusal, akademik becerilerin değerlendirilmesi gerektiğini, bu sayede çocukların desteklenmeye ihtiyaç duyulan yönlerinin tespiti ve ailelere rehber olmak amacıyla değerlendirme yaptıklarını ifade etmişlerdir. Aynur'un "Çocukların gelişimlerini kontrol ederek normal gelişimleri takip etmek ve çocuğun eksik kalan yerleri aile öğretmen işbirliği içerisinde çözülebilmesini sağlamak amacıyla değerlendirme yapıyorum." ifadesinde, normal gelişim gösteren çocukların öğrenme sürecini takip etmek ve gerektiğinde aileden destek almak için değerlendirme yaptığı görülmektedir. Öğretmenlerden Aynur değerlendirmenin özellikle çocuklara hazırlanacak olan eğitim etkinliklerinin planlanması için önemli olduğunu aşağıdaki ifadeleri ile vurgulamıştır:

\footnotetext{
Öğrenmenin en hızlı olduğu dönem okul öncesidir ve çocuğun ne kadar yol kat ettiğinin (ortaya konmasının) en iyi yolu objektif değerlendirmedir. Değerlendirmede, neyi ne kadar öğrenmiş, ne kadar kalıcı olmuş ve hayatına nasıl adapte etmiş, farklı alanlarla birleştirip kullanabiliyor mu gibi değişkenleri göz önünde bulundurmalıyız diye düşünüyorum. Çocukların zamanla ne kadar geliştiğini görebiliyorum. Çocuklar öğrendi mi? öğrenmedi mi? öğrenmediyse nasıl, hangi tekniklerle etkinliklerle öğretmeliyim. Bu sorularımın cevabını da çocukları değerlendirmelerim sonucunda karar veriyorum.
}

Yukarıdaki ifadelerden de anlaşılacağı gibi yeterliliği yüksek olan öğretmenlerin eğitim sürecinde 
çocukların güçlü yanlarını ve ihtiyaçlarını belirlemek, öğrenmelerine ilişkin eğitimcilere, ailelere, çocuklara kanıt toplamak, uzun ve kısa dönemli eğitim programları hazırlayabilmek, özel eğitim hizmetlerinden yararlanma durumlarını belirleyerek ilgililerle (özel eğitim öğretmeni, psikolojik danışman ve rehber öğretmen, Rehberlik Araştırma Merkezi [RAM]) bilgi paylaşımında kullanmak amacıyla değerlendirme yaptıkları görülmektedir.

Yeterlilik düzeyi düşük olan öğretmenlerin ise "ailelere bilgi vermek", "çocukların ilgi alanlarını belirlemek", "desteklenmesi gereken yönlerini tespit etmek" amaçlarıyla değerlendirmeler yaptıkları görülmektedir. Çocukların sosyal-duygusal gelişim alanlarını tespit etmeye yönelik değerlendirme yapan Zeynep'in ifadesi aşağıdaki gibidir:

Sosyal duygusal alan, çocukların sosyalleşmesi, duygusal anlamda becerilerin kazanılması, paylaşması bizim için çok önemli. Bu alanda oyun endeksli her alana dokunmaya özen gösteriyorum. Örneğin çok içine kapanık bir çocuğum olduğunu belirlediğimde onu daha aktif katılacağı etkinliklere yöneltiyorum ya da çok hareketli çocuğum varsa daha çok koşuşturmacalı oyunlar da oynatıyorum.

Öğretmenlerden Züleyha'nın "Ailelerin beklentisi çok fazla oluyor bazen benim çocuğum ne yaptı şeklinde sorular soruyorlar, onlara dönütler veriyoruz." ifadesinden ailelere dönütler vermek için değerlendirme yaptığı anlaşılmaktadır. Öğretmenler aynı zamanda çocukların ilerideki okul hayatına yardım sağlamak amacıyla değerlendirme yaptıklarını belirtmişlerdir. Sosyal, bilişsel gelişim düzeylerinin desteklenmesi amacıyla yaptıkları değerlendirmelere ilişkin Zübeyde öğretmenin "Çocuklar neyi yapıyor neyi yapamıyor kendileri de farkında olmalılar. Benim çocuklarım altı yaş. Gelecek yıl ilkokula gidecekler. Onların okuma, yazma ve matematik becerilerinde belirli kazanımları elde etmesi gerekiyor." ifadelerinden anlaşılmaktadır.

Bunun yanında, Zehra öğretmenin "Etkinliğin sonunda gerekli kavram ve becerileri kazanıp kazanmadığını anlıyorum. Olmadıysa daha başka farklı yöntem ve teknikler muhasebesi için illaki değerlendirme gerekiyor." ifadeleri ile eğitim sürecini takip etmek, kavram ve becerilerin ulaşılabilirliğini tespit etmek amacıyla değerlendirme yaptığı görülmektedir. Özetle yeterlilik düzeyi düşük öğretmenlerin, çocukların gelişimlerinin takip edilmesi, eğitim programında düzenlemelerin yapılması ve ailelere bilgi vermede kanıt olarak sunmak için değerlendirme yaptıkları görülmektedir.

Sonuç olarak yeterlilik düzeyi düşük ve yüksek olan öğretmenlerin değerlendirme yaparken birleştikleri ve ayrıldıkları noktalar bulunmaktadır. Her iki grup öğretmenlerin de çocukları tanımak, çocukların sosyalduygusal, bilişsel, dil ve motor becerilerini takip etmek, eğitim durumunu düzenlemek, ailelere bilgi vermek amacıyla değerlendirme yaptıkları görülmektedir. Yeterlilik düzeyi yüksek olan öğretmenler bunlara ek olarak gelişimsel bir problemin tespiti ve takibi, RAM, psikolojik danışman ve rehber öğretmen ve özel eğitim öğretmeni ile paylaşırken kanıt olarak sunmak için değerlendirme yapmaları düşük düzeydeki öğretmenlerden ayrılan bir bulgudur. Yeterliliği düşük olan öğretmenler çocukların değerlendirmelerini RAM, psikolojik danışman ve rehber öğretmeni ve özel eğitim öğretmeni ile paylaşılmasına ilişkin hiçbir ifadede bulunmamaları ilgi çekicidir.

\section{2) Neyi değerlendiriyorum?}

Yeterlilik düzeyi yüksek olan öğretmenlerin, çocukların bilişsel, psiko-motor, dil gelişimlerini, öz bakım becerilerini değerlendirdikleri saptanmıştır. Örneğin Asu'nun aşağıdaki ifadesinden çocukların dil ve bilişsel gelişim alanlarına odaklandığı anlaşılmaktadır:

Kas becerilerinin kendiliğinden geliştiğine inanıorum. Üzerine yoğunlaşmasak da çocukların bir şekilde bunu ilerleteceğini düşünüyorum. Özellikle bilişsel ve dil gelişiminin ve öz bakım becerilerinin üzerinde çalışılması gerektiğini düşünüyorum. Özellikle bu dönemde çocukların dil gelişimiyle ilgili ne kadar üstüne gidersek, eğilirsek ileride o kadar faydasını göreceğini düşünüyorum.

Buna karşın Arzu ise çocukların psiko-motor becerilerini değerlendirmenin önemli olduğunu “Motor becerileri yaptığımız sanat etkinlikleriyle değerlendiriyorum. Her çocuğun motor becerileri farklı olabiliyor. Bazılarının çok iyi iken bazılarının biraz daha geriden gelme durumları oluşabiliyor. Onlara endekslenerek, onların bu becerilerini aramıza dâhil etmeye çalışarak ve basitten zora... bu şekilde başlıyorum." ifadesiyle belirtmiştir. 
Arzu'nun yukarıdaki ifadelerinden çocukların motor gelişimlerini değerlendirdiği ve değerlendirme sonuçlarına göre ihtiyacı olan çocukları desteklediği görülmektedir. Alev'in ise "Benim için gelişim önem sıralamasında ahlaki gelişim ve sosyal duygusal gelişim önemli, diğerleri bir şekilde geç de olsa tamamlanıyor." ifadesiyle çocukların sosyal ve duygusal gelişimlerini değerlendirdiği görülmektedir. Aynur'un "Bilişsel anlamda hikâyeler değerlendirme açısından bizim olmazsa olmazlarımız. Çocuklara Türkçe etkinliklerinde hikâyeden sonra sorular soruyorum, anlama becerilerine odaklanıyorum." ifadeleri ile değerlendirmede bilişsel ve dil gelişimlerine odaklandığını belirtmiştir. Öğretmenler yaptıkları gelişimsel değerlendirme sonuçlarına göre günlük eğitim akışlarını düzenlediklerini, desteğe ihtiyaç duyan çocuklara da eğitsel etkinlikler eklediklerini belirtmişlerdir. Örneğin Alev'in, “Özellikle kazanım ve göstergelere göre ek etkinliklerle, sosyal anlamda arkadaşlık duygularına değinmeyle, oyunla bağdaştırmaya desteklemeye çalışıyorum." ifadesinden özel gereksinimli çocuklara ek etkinliklere karar verirken kazanım ve göstergeleri göz önünde bulundurduğu anlaşılmaktadır.

Yeterlilik düzeyi düşük olan öğretmenlerin de çocukların gelişim alanlarına yönelik değerlendirme yaptıklarını tespit edilmiştir. Öğretmenlerin daha çok çocukların sosyal ve duygusal alanlara odaklandıkları Zehra'nın aşağıdaki ifadesinde görülmektedir:

\begin{abstract}
Ben akademik gelişime çok fazla takılmıyorum. Akademik gelişimi okul öncesinde çok önemli görmüyorum. Çünkü ilerleyen döneminde çocuklar bu alanda, yani akademik anlamda, bir sürü eğitim alacaklar. Okul öncesinin böyle bir alan olduğunu düşünmüyorum. Bana daha çok sosyal ve duygusal alan en önemli geliyor. Bilişsel anlamda çok da üzerine gidilmemeli çocuğun yapabildiği kadar diye düşünüyorum. Onu sarsacak kadar içine kapatacak kadar akademik anlamda tutkularımız olmamalı..
\end{abstract}

Benzer şekilde Zülal'in, “Benim için gelişim önem sıralamasında ahlaki gelişim ve sosyal duygusal gelişim önemli, diğerleri bir şekilde geç de olsa tamamlanıor." ifadeleri ile değerlendirmede sosyal, duygusal gelişime önem verdiği anlaşılmaktadır.

Sonuç olarak yeterlilik düzeyi yüksek ve düşük olan öğretmenlerin çocukların sosyal, duygusal ve dil gelişimlerine odaklandıkları, bunları takip etmek, geliştirmek ve gerekli önlemleri almak amacıyla değerlendirme yaptıkları görülmüştür. Bunlara ek olarak yeterlilik düzeyi yüksek olan öğretmenlerin çocukların bilişsel gelişimine, yeterlilik düzeyi düşük olan öğretmenlerin ise ahlak gelişimini de önem verdikleri görülmektedir. Her iki düzeydeki öğretmenlerin de programın değerlendirme ve kendilerini değerlendirme ile ilgili ifadeleri kullanmamaları ilgi çekicidir.

\title{
3) Nasıl değerlendiriyorum ve belgelendiriyorum?
}

Yüksek yeterlilik düzeyindeki öğretmenler çocukları değerlendirirken MEB okul öncesi eğitim programında yer alan kazanım ve göstergeleri esas aldıkları, kazanım-gösterge kontrol çizelgelerinden faydalandıkları saptanmıştır. Asu okul öncesi eğitim programında yer alan gelişim özellikleri, kazanım ve göstergeleri kullandığını “Genel olarak kavramlarla ilişkilendirmeye çalışıyoruz. Bir de MEB'in değerlendirme tablosundan özellikle yararlanıyoruz." ifadeleriyle belirtmiştir. Buna ilave Aylin ise çocukların yaş gruplarına göre değerlendirmede bulunduğunu aşağıdaki sözlerle belirtmiştir.

Her çocuğun farklı, önde olduğu alanları var. Kimisinin dili çok iyi kimisinin bilişsel gelişimi çok iyi, ama atıyorum ki motor gelişiminin biraz desteklenmeye ihtiyacı var. Bunları değerlendirirken de her çocuk için geçerli olan kazanım değerlendirme formlarımız var onları baz alıyoruz. Ayda bir değerlendiriyorum. İlk önce çocukları tabiî ki de hangi yaş grubunun neler yapıp neler yapamayacağını kazanım ve göstergelere bakarak belirleyip gözlemleyerek değerlendiriyorum. Kazanım değerlendirme formuna işaretleme yapıyorum.

Yeterlilik düzeyi düşük olan öğretmenlerin MEB okul öncesi eğitim programındaki kazanım ve göstergeleri bildikleri ancak kendi değerlendirmeleri sonucu kayıt altına almaya ihtiyaç duymadıkları görülmektedir. Zülal öğretmenin aşağıdaki ifadelerinden kendi kanaatleri doğrultusunda bir yargıya vardığı, her ne kadar gelişim kontrol çizelgelerini bilse de kullanmaya ihtiyaç duymadığı görülmektedir:

Değerlendirme yaparken kazanım ve göstergelere bakıyorum. Bir de kavram çizelgemiz var aylık olarak. Kavramları biliyorlar mı bilmiyorlar mı kontrol ediyorum. Çoğu zaman bildikleri kavramlar oluyor o yüzden çok da gerek kalmıyor. Motor becerileri sanat etkinliklerinde ölçebiliyoruz. Makas tutabiliyor mu yapıştırabiliyor mu katlayabiliyor mu?

Yeterlilik düzeyi yüksek olan öğretmenler çocukların gelişimleri ile ilgili gözlem sonuçlarını 
kaybetmemek ve detaylı bilgi sunabilmek, önemli bir durumun farkında olabilmek amacıyla gözlemleri kayıt altına aldıklarını belirtmişlerdir. Aynur'un "Serbest zamanda onlarla oyun oynarken farklı durumlarla karşılıyorsam olumsuz durumlar yaşıyorsam gözlem formuna değil de bir not defterim var ona not alıyorum. Veliyle de bir problem durumunda paylaşıp iş birliği yapıyorum." ifadesiyle çocuklardaki olumsuz davranışların tespitinde gözlemlerini kayıt altına aldığı anlaşılmaktadır.

Yeterliliği yüksek olan öğretmenlerin "sistematik gözlem" ve "çocukların ürünlerini toplama" yoluyla değerlendirme yaptıkları saptanmıştır. Öğretmenlerin genellikle serbest zaman ve oyun etkinleri süresi boyunca gözlem yoluyla değerlendirme yaptıkları Şekil 1.a'da görülmektedir. Öğretmenlerden Ahu gözlemle ilgili görüşlerini “Çocuklar yetişkinler gibi kendilerini iyi ifade edemediği için oyun sırasındaki gözlemler çok önemlidir. Biz öğretmenler için çok pratik oluyor. Ayrıca bir zamana ihtiyaç duymadan özellikle merkezlerde oynarken gözlem yapabiliyorum." şeklindeki ifadesiyle oyun sırasında gözlemi kullanmanın avantajlarını belirtmiştir (Şekil 1.a).

Ayrıca öğretmenlerin yaptıkları gözlemleri kayıt altına almaya önem verdikleri; "anekdot kaydı", "gözlem defterleri", "rubrik" ve "işaretleme listeleri" yoluyla belgelendirdikleri görülmektedir. Aylin; "En çok gözlem kullanıyorum, gözlemin çok etkili olduğunu düşünüyorum. Kazanım değerlendirme formuna işaretleme yapıyorum ve gözlem kayıtlarımı tutuyorum." ifadesiyle işaretleme listelerini kullandığını belirtmiştir. Öğretmenler çoğunlukla anekdotları kaydederken defter tutma yoluna gittikleri görülmüştür. Örneğin, Arzu "Defterin içerisine anekdotları yazıyorum, eğer çok gerekli bir durum olursa onları da aileyle ayrı bir şekilde paylaşıyoruz." ifadelerini kullanırken Asu, "Günlük defter tutuyorum. Çocukları hiç gözlemiyormuşuz gibi düşünüyoruz ama deftere yazarken, o an o gün ne yaşandıysa her şeyi hatırlıyorum gözlemlerimi yazarsam." ifadesiyle gözlemlerini kayıt altına alma yöntemlerini belirtmişlerdir. Öğretmenler gözlem kayıtlarını tutarken objektif ifadeler kullandıklarını ifade etmişlerdir. Asu: "Bu kayıtlarla öğretmen veliye çocuğunuz süper demektense çocuğunuz şunu yapabiliyor şunu yapamıor şeklinde bilgi veriyor." ifadelerini kullanırken Aynur gözlem kayıtları tutarken nesnel olduğunu "Gözlemleri çocuk şunu çok seviyor, şunu yapıyor şeklinde değil, matematik etkinliğinde şunu yaptı, müzikte şunu yaptı, böyle olsa daha iyi olur şeklinde yazıyorum. Ailelere de genel bir bilgilendirme oluyor." ifadesiyle belirtmiştir (Şekil 1.b).

Katılımcı öğretmelerin gözlem kayıtlarını tutarken gerek duyulması halinde farklı teknikleri diğer uzmanlar ile işbirliği içerisinde uyguladıkları, Alev'in "Bir de bir çocukla saati saati gözlem raporu tutmuştum, özel bir durum vardı. Okulumuzun psikolojik danışmanı ile rubrik yapmıştık. Danışmanın verdiği testi uygulamıştım." ifadesinden anlaşılmaktadır.

Yeterlilik düzeyi yüksek öğretmenlerin bir değerlendirme aracı olarak portfolyoyu kullandı̆̆ı görülmektedir. Portfolyoyu kullanan öğretmen Arzu'nun, “Portfolyoları her dönemde bir tane olacak şekilde senede iki defa hazırlıyorum. Portfolyolarımı oluştururken çocukların günlük etkinliklerini dolaplarında biriktiriyoruz. Grupla yaptığı çalışmaları çoğunlukla fotoğraflıyorum. Dönem sonuna doğru çocuk ben ve çoğunlukla annesi dosyaya koymak istediğimiz etkinlikleri belirliyoruz." ifadesinden portfolyoyu ebeveynlere çocuğun gelişimini somut bir şekilde kanıtlayabilmek için hazırladığı anlaşılmaktadır. Alev ise, "Porfolyo kullanmak, çok zaman alan bir şey. Portfolyo çocuğun bir yıl boyunca neler yaptı̆̆ını nereden nereye geldiğini hangi süreçleri izlediğini gösteren bir dokuman bence. Bunu aile belki gözlemleyebiliyor. Portfolyo aileye, çocuğa ve öğretmene büyük kanit. Çocuk neredeymiş, nereye gelmiş?" ifadesiyle portfolyonun faydalı olduğunu fakat pratik bir değerlendirme aracı olmadığını belirtmiştir. Alev öğretmenin bir çocuğun gelişimini kronolojik sırayla portfolyoda biriktirdiği ev resimleri Şekil 2'de görülmektedir.

Öğretmenlerden Arzu, oyun temelli değerlendirmeyi daha önce duymadığını “Oyun temelli değerlendirmeyi çok fazla bilmiyordum. Sizin sayenizde duydum." şeklinde belirtirken öğretmenlerden Alev oyun temelli değerlendirmeyi sınıflarının olumsuz şartlarından dolayı kullanmadığını aşağıdaki ifadelerinden anlaşılmaktadır:

Bir oyunda sistematik gözlemde çocuğun hangi durumda nasıl cevap verdiğini arkadaşıyla nasıl konuştuğunu gözlemliyoruz ama yazıya dökerken unutabiliyor insan. Bizde de öğrenci sayısı fazla olduğu için sistematik oyun gözlem formunu doldururken aksaklıklar oluyor, her an yapamıyoruz. Kayıt için öğretmen dışında sınıfta birisinin olması lazım ki onları değerlendirebileyim. 
Öğretmen Asu'nun “Önce oyunu kendim oynuyorum, sonrasında çocukların oynamasına izin veriyorum, sonra izleyen öğretmen olarak oyunu yapıp yapamadıklarını, gözlemci olarak çocukların oyun hızını değerlendiriyorum." ifadesinden oyun temelli değerlendirme ile ilgili kavram yanılgısının olduğu görülmektedir.

Yukarıdaki ifadelerden yeterlilik düzeyi yüksek olan öğretmenlerin çoğunlukla gözlem yoluyla değerlendirme yaptıkları, çeşitli yöntemlerle kayıt altına aldıkları görülmektedir. Bunun dışında öğretmenlerin portfolyo değerlendirmelerini de kullandıkları tespit edilmiştir. Öğretmenlerin bu gelişim raporlarını, veliler ve gerektiğinde psikolojik danışman ve rehber öğretmenlerle paylaştıkları bulunmuştur. Buna karşın öğretmenlerin görüşme, standart testler veya alternatif değerlendirme yöntemlerine ilişkin hiçbir görüş bildirmemeleri dikkat çekicidir.

Yeterlilik düzeyi düşük olan öğretmenler çocukları değerlendirirken çoğunlukla serbest zaman oyun süresinde gösterdikleri davranışlara odaklandıklarını, "gözlem" ve "portfolyo" yöntemleri ile bilgi topladıkları tespit edilmiştir. Zehra'nın, "Sosyal ve duygusal gelişimlerini gözlem yöntemiyle değerlendiriyorum.... Başka bir yöntem kullanmıyorum."; Zülal'in, "En çok serbest zamanda gözlem yapıyorum. Oyun oynarken en doğal hallerini gözlemleyebiliyorum. Daha sonrasında aileleriyle günlük olarak paylaşıyorum." ve Zeynep'in, "Serbest zaman etkinliklerinde hangi durumlarda nasıl davrandıklarını gözlemeyi seviyorum. Bu onların sosyal ve duygusal gelişimleri açısından bana çok güzel bilgiler sunuyor." ifadelerinden çocukların gruplaşarak öğrenme merkezlerinde oynadıkları günün ilk saatlerinde, katılımsız gözlem yaptıkları anlaşılmaktadır.

Yeterlilik düzeyi düşük olan öğretmenler yaptıkları gözlemleri kaydetmediklerini, değerlendirmede farklı teknikleri kullanmadıklarını, sadece dikkat çeken durumlarda gözlem yaptıklarını, düzenli gözlem yapmadıkları görülmektedir. İlgililerin gözlem veya görüşme gibi kayıtları istememesi, zorunlu olmaması gibi sebeplerden dolayı kayıt altına almadıkları tespit edilmiştir. Zübeyde kayıt tutmadığını şu şekilde ifade etmektedir:

Farklı yöntemler kullanmıyorum. Dikkat çeken durumlarda zaten çocuk beni gözlemle diyor gözlem kayıtlarını tutmak için herhangi bir araç kullanmıyorum kaydetmiyorum. Daha çok yani sıcağı sıcağına müdahale etmeye çalışıyorum ve aile ile hemen paylaşıyorum ama öyle bir kayıt tutup bulundurduğum yok. E-okula çocukları dönem sonu değerlendirmemiz isteniyor. Bunun dişında bizden bir şey istenmiyor zaten.

Zehra ise düzenli olarak gözlem yapmadığını "Haftada belli bir şekilde değil, zaten sürekli sınıfın içindeyiz, dikkatimi çeken şeyleri alıyorum. Düzenli bir kayda geçirme şeklim yok." ifadeleriyle belirtmiştir.

Katılımcı öğretmenler çoğunlukla gözlem sonuçlarını kayıt altına almayı gerekli bulmadıklarını, günlük olarak aile ile sözel paylaştıklarını ifade etmişlerdir. Zeynep, farklı değerlendirme araçlarını sınıflarının çok kalabalık olmasından dolayı kullanmadığını aşağıdaki ifadeleriyle belirtmektedir:

Değerlendirme aracı olarak rubrik vs. kullanmıyorum. Çünkü 26 çocukla buna gerçekten büyük bir özveri göstermem ve zaman ayırmam gerekiyor. Bu kadar kalabalık sınıfta kullanmam gerçekten mümkün değil. Bunu denedim aslında ama beceremedim bir çocukla ilgilenirken diğerlerini aksatmak durumunda kalıyorum. O yüzden kullanmıorum. Ama az sayıda çocukla tabii ki kullanılabilir.

Katılımcı öğretmenler ile yapılan görüşmelerden bazı öğretmenlerin değerlendirme aracı olarak portfolyo dosyası tuttukları bazılarının ise porfolyoyu kullanmadıkları bulgusu elde edilmiştir. Katılımcı öğretmenlerden Zeynep portfolyoya gerek olmadığını "Portfolyoya gerek duymuyorum, çünkü her hafta velileri arayıp çocukları anlatıyoruz, günlük olarak da defterlere yazıyoruz." ifadesi ile belirtirken Züleyha, portfolyoları hazır etkinlik dosyaları alarak oluşturduğunu (Şekil 3), fiziki şartlardan dolayı okulda muhafaza etmediğini "Portfolyo dosyasını hemen hemen her yıl hazır şablonu kullanıyordum. Pratik oluyordu. Fakat bu kadar geniş kapsamlısını bu yıl ilk kez kullanacağım. Portfolyolar tatbikî önemli ama daha çok sınıf küçük eve gönderiyorum." ifadesi ile belirtmiş; Zübeyde ise farklı bir uyguma yapacağını çocuk ve aileyi birlikte oluşturacağını aşağıdaki ifadeler ile açıklamıştır:

Geçtiğimiz yıllarda portfolyo dosyasını sene sonunda evlere gönderiyordum fakat bu yıl farklı bir planım var. Bu yıl sene sonuna doğru mayıs aylarında hafta sonu her çocuk için belirli bir gün ve zaman ayıracağım. Aile-çocuk-öğretmen eşliğinde bu portfolyoyu çocuk ailesine sunacak, öğretmen olarak rehberlik edeceğim. 
Sonuç olarak yeterlilik düzeyi düşük ve yüksek olan öğretmenlerin, çocukları değerlendirmede kullandıkları ortak yöntem gözlem ve portfolyodur. Öğretmenler çocukları değerlendirme ortamı olarak sınıfı tercih ettiklerini, özellikle öğrenme merkezlerinde çocuklar akranları ile oyun oynarken gözlem yaptıklarını ifade etmektedirler. Yüksek düzeyde olan öğretmenlerin buna ilave olarak gelişim kontrol listelerini kullandıkları bulunmuştur. Yeterlilik düzeyi yüksek öğretmenler yaptıkları gözlemleri kayıt altına almaya daha çok önem verdikleri görülmüştür. Yeterlilik düzeyi düşük öğretmenler ise gözlem sonuçlarını kayıt etmek yerine günlük, ailelerle sözel olarak paylaştıkları saptanmıştır. Standart testler, alternatif değerlendirmeler her iki seviyedeki öğretmenler tarafından da kullanılmamaktadır.

\section{Dokümanlardan gözlem kayıtlarına ilişkin bulgular}

Katılımcı öğretmenlerin tutukları gözlem raporlarına incelendiğinde yeterlilik düzeyi yüksek ve düşük öğretmenler arasında farklılıklar saptanmıştır. Yeterlilik düzeyi düşük olan öğretmenlerin gözlem kayıtlarının rutin ve gayri resmi olduğu görülürken, yeterlilik düzeyi yüksek olan öğretmenlerin ise sistematik, odaklanılmış ve bilgi toplamayı amaçlayan gözlem kayıtları topladıkları tespit edilmiştir. Yeterlilik düzeyleri yüksek öğretmenlerin daha çok bir çocuğun belirli bir davranış örüntüsüne veya probleme odaklandıkları, bir hedef doğrultusunda gözlemlerini kaydettikleri görülmektedir (bknz. Şekil 1).

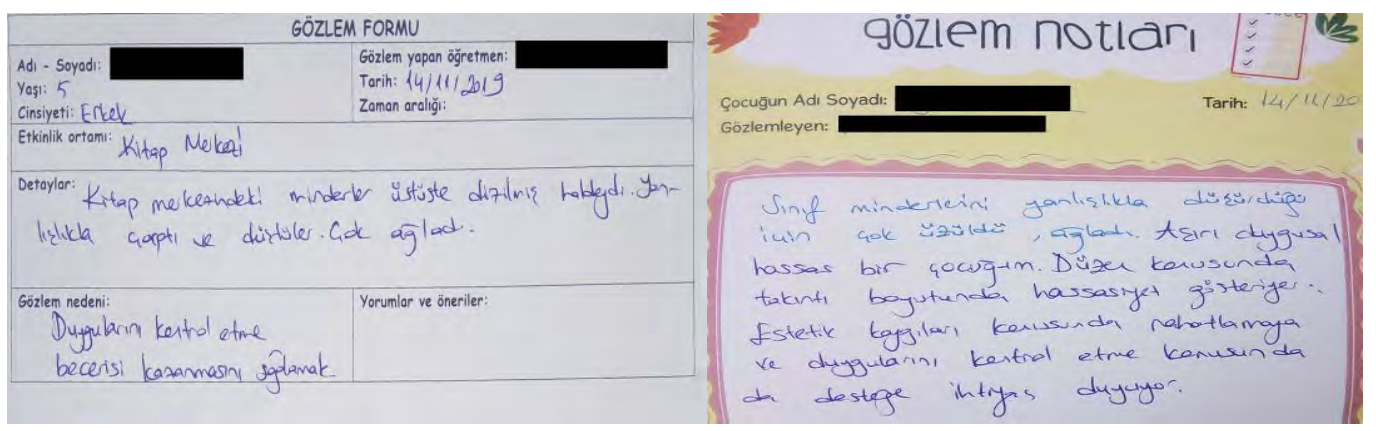

Şekil 1. Yüksek yeterlilik düzeyindeki Ahu öğretmenin gözlem kayıtları

\section{Dokümanlardan portfolyolara ilişkin bulgular}

Yeterlilik düzeyi yüksek olan öğretmenlerden elde edilen portfolyo içerisinde yer alan çocukların yaptıkları resimler incelenmiştir. Bu incelemeler sonucu öğretmenlerin çocukların gelişimlerini süreç içerisinde değerlendirebilmek için resimleri kronolojik sıra ile biriktirdikleri, yılsonunda çocuğun gelişiminin göstergesi olarak ailelere kanıt olarak sundukları görülmüştür. Örnek portfolyo dokümanları Şekil 2'de gösterilmiştir.

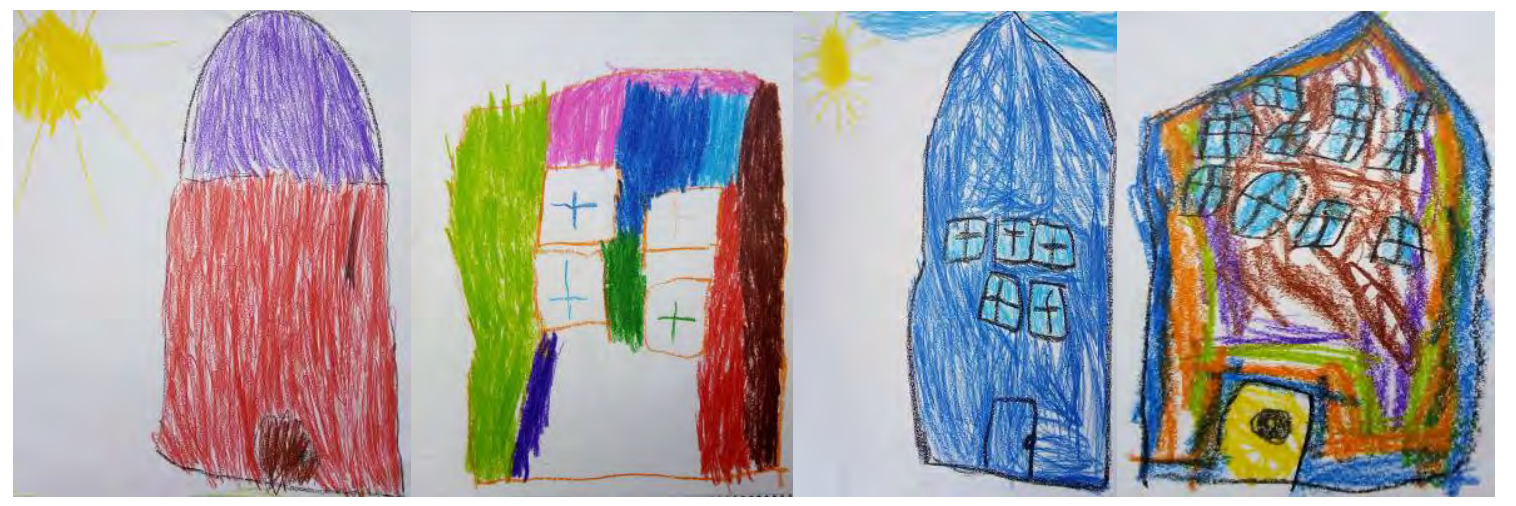

Şekil 2. Alev öğretmenin yıl boyunca K.E. isimli çocuğun gelişimini göstermek amacıyla kronolojik sıra ile topladığı ev resimleri

Öte yandan yeterlilik düzeyi düşük olan öğretmenlerden elde edilen portfolyo örnekleri ise farklı bir durumu ortaya koymaktadır. Bu öğretmenler portfolyo olarak çocukların ürünlerinin tarihsel bir sıralama olmaksızın biriktirildiği ve bu dosyada sıklıkla çocukların sanat ve akademik becerilerini gösteren örneklerin olduğu görülmektedir. Yeterlilik düzeyi düşük öğretmenlerin portfolyo sayfası örneği Şekil 3'te gösterilmiştir. 


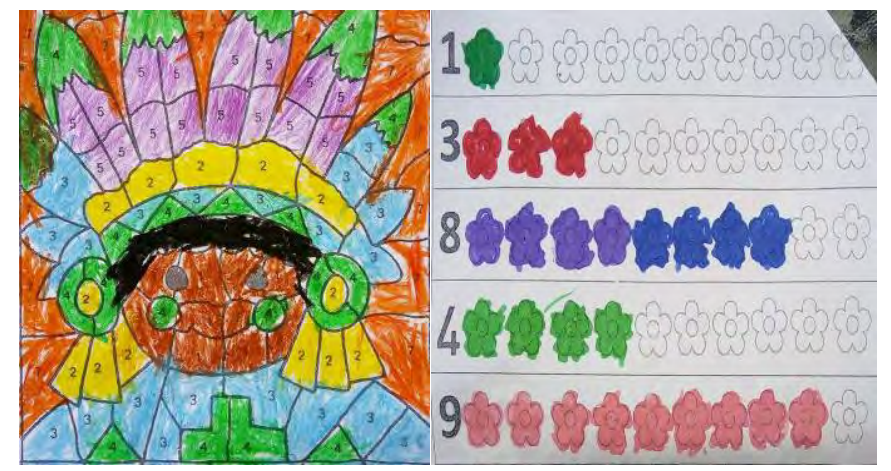

Şekil 3. Düşük yeterlilik düzeydeki Züleyha öğretmenin çocukların gelişimini desteklemek ve takip etmek için kullandığı etkinlik örnekleri

\section{Sonuç ve Tartışma}

Okul öncesi öğretmenlerinin çocukların gelişimlerini değerlendirmede kullandıkları araçlar ile onları tanıma ve değerlendirmedeki yeterlilik düzeylerinin incelendiği bu araştırmada dört önemli sonuç ortaya çıkmıştır. İlk olarak, bu araştırmada okul öncesi öğretmenlerinin çocukları tanıma ve değerlendirme hususunda çok büyük bir kısmının orta ve düşük düzeyde bilgiye sahip olduğu saptanmıştır. Çocukları tanıma ve değerlendirme ile ilgili yeterli bilgi sahibi olmadan öğretmenlerin değerlendirmelerini sağlıklı yapmaları ve dolayısıyla çocuk ve ailelere kaliteli eğitim hizmeti sunabilmeleri tartışmalara açıktır (Snow ve Van Hemel, 2008; Yılmaz ve Zembat, 2019). En genel anlamda çocukların okula başladıklarında ne bildikleri ve neleri yapabildiklerinin öğretmen tarafından değerlendirilmesi ve bu değerlendirmeden hareketle sınıf içi öğrenmelerin düzenlenmesi kaliteli eğitim için önemli bir gerekliliktir (Fantuzzo, Tighe ve Childs, 2000; Lidz, 2002; Meisels ve Atkins-Burnett, 2000). Değerlendirmeyi nasıl yapacaklarına dair bilgi eksikliğinin öğretmenlerin uygulamalarına yansıdığı da ayrıca araştırmanın bir sonucu olarak saptanmıştır. Bu nedenle çocukları tanıma ve değerlendirmeye yönelik hizmet içi eğitim çalışmalarının yapılması önerilmektedir. Özellikle gelişimsel tarama araçları, sistematik gözlem, portfolyo kullanımı gibi temel konularda öğretmenlerin eksiklerinin giderilmesi okul öncesi sınıflarda değerlendirmelerin yapılmasını destekleyecektir.

İkinci olarak, bu araştırmada öğretmenlerin çocukları değerlendirme amaçları belirlenmiştir. Yeterlik düzeyi yüksek ve düşük olan öğretmenlerin çocukları değerlendirme amaçları pek çok ortak özellik göstermekle birlikte değerlendirme verilerinin paylaşılması hususunda farklılaşmaktadır. Her iki öğretmen grubunun da çocukların gelişimsel sürecini izlemek, ihtiyaca uygun eğitim planı hazırlamak, ailelere bilgi vermek amacıyla değerlendirme yaptığı saptanmıştır. Yüksek düzeyde yeterliğe sahip olan öğretmenler değerlendirme verilerini rehber öğretmen veya özel eğitim öğretmeni ile paylaşırken, düşük düzeyde yeterliğe sahip öğretmenlerin değerlendirme verilerini sadece ailelerle paylaşmaları ilgi çekicidir. Değerlendirme süreçlerinde elde edilen bilgiler, çocukların gelişimlerini ve öğrenme süreçlerini takip etmek, çocukların öğrenme süreçlerine rehber olmak, özel eğitimden yararlanacak çocukları tespit etmek ve ilgili kişilerle iletişim kurup rapor sunmak amacıyla kullanılmaktadır (McAfee ve Leong, 2012). Araştırmada değerlendirme sürecinde elde edilen bilgilerin özel yardıma ihtiyaç duyacak çocukların tespiti için kullanılmaması, bu hizmetlerden yararlanacak çocukların ilgili kişilere bildirilmemesi erken tanı ve tedavi hizmetlerinden yararlanmayı geciktirebilmektedir.

Üçüncü olarak, öğretmenlerin değerlendirme sürecinde neleri değerlendirdikleri tespit edilmeye çalışılmıştır. Her iki öğretmen grubunun da çocukları gelişim alanlarına göre değerlendirdikleri fakat bütüncül bir değerlendirmeden ziyade çocukların bilişsel, dil, sosyal ve duygusal gelişim alanlarına daha çok önem verdikleri tespit edilmiştir. Buna karşın çocukların motor becerilerin süreç içerisinde kendiliğinden gelişeceğini düşünmeleri dikkat çekicidir. Alanyazın öğretmenlerin çocukları değerlendirirken tüm gelişim alanları ve öğrenmeyi kolaylaştıran farklı disiplinleri (fen, matematik, beslenme, fiziksel sağlık, yaratıcı sanat, erken okuryazarlık gibi konularda) bir arada uyumlu bir şekilde bağdaştırarak değerlendirme süreçlerinde neyin değerlendirileceğine karar verilmesi gerektiğini vurgulamaktadır (McAfee ve Leong, 2012). 
Son olarak, yeterlilik düzeyi düşük ve yüksek olan öğretmenlerin, çocukları değerlendirmede sıklıkla kullandıkları yöntemin gözlem ve portfolyo olduğu saptanmıştır. Yüksek düzeyde yeterliğe sahip öğretmenlerin ayrıca gelişim kontrol listelerini kullandıkları görülmüştür. Yeterlilik düzeyi yüksek öğretmenler gözlemlerini kayıt altına almaya daha çok önem verirken yeterlilik düzeyi düşük öğretmenlerin gözlem sonuçlarını kayda geçirmeksizin ailelerle ihtiyaç halinde sözel olarak paylaştıkları saptanmıştır. Yüksek düzeyde yeterliğe sahip öğretmenlerin portfolyo dosyası edindikleri ve düşük düzeyde yeterliğe sahip öğretmenlerin ise sınıf mevcudunun kalabalık olması gibi nedenlerden ötürü portfolyo dosyası edinmedikleri görülmüştür. Düşük düzeyde yeterliğe sahip öğretmenlerin, ilgili kişilerin çocukları değerlendirmeye ilişkin raporları istememesi, bu kayıtların tutulmasının zorunlu olmaması ve sınıf mevcudunun kalabalık olması gibi nedenlerden dolayı uygun değerlendirme yöntemlerini kullanmadıkları tespit edilmiştir. Üstelik her iki öğretmen grubunda standart testleri ve alternatif değerlendirme yöntemlerini hiç kullanmadıkları ve bu konularda bilgilerinin olmadığı saptanmıştır. Bu durum okul öncesi eğitimi öğretmenliği lisans programında çocukları tanıma ve değerlendirmeye yönelik derslerin sınırlı olması ve bu derslerde alternatif değerlendirme yaklaşımlarına yeterince yer verilmemesi ve standart testleri daha fazla psikolojik hizmetlerden sorumlu rehber öğretmenlerin kullanmasının teşvik edilmesi ile açılanabilir. Öte yandan, tarama testleri gibi bazı standart araçları okul öncesi öğretmenleri de kullanabilmektedirler. Bu nedenle öğretmenlerin uygun olan standart araçları ve alternatif değerlendirmeyi kullanmaları için eğitim almaları yararlı olacaktır.

Yapılmış benzer araştırmalarda okul öncesi öğretmenlerinin, çocukların gelişimini takip etmek için sadece kazanım değerlendirme formları ve gelişim raporları kullandıklarını (Furat, Usta Sayın ve Uluman, 2012); genellikle gözlem ve görüşme teknikleri ile çoğunlukla sistematik gözlem, oyun gözlem formu doldurduklarını ve anekdot kaydı tuttuklarını (Yılmaz Topuz ve Erbil Kaya, 2016); çocukları değerlendiren profesyonellerin en sık kullandıkları araçların standart testler olduğunu, standart olmayan araçlardan ise en çok gözlem, oyun temelli değerlendirme ve gelişim kontrol listesi (Banerjee ve Luckner, 2013) kullanıldığını saptamışlardır. Ayrıca çocukları değerlendirme sürecinin anaokulunda büyük bir özenle yapıldığı; ancak sistematik olarak değerlendirme sürecinde kullanılan formların çocuklarla ilgili yüzeysel amaçları olup sınırlı bilgiler içerdiği (Nah ve Kwak, 2011) bulunmuştur. Okul öncesi öğretmenlerinin ölçme ve değerlendirme konusunda bilgi eksikliklerinin giderilmesi için günümüzde kullanılan farklı değerlendirme yöntemlerinin tanıtılması ve alanda uzman kişilerin öğretmenlere uygulamalı eğitimler vermesi gerekmektedir. Okul öncesi öğretmenliği bölümünde okuyan öğrencilerin üniversitede aldıkları ölçme ve değerlendirme dersinin kapsam ve içeriğinin yeniden düzenlenerek erken çocukluk eğitiminde çağdaş ölçme ve değerlendirme yaklaşımları eklenmelidir. Ayrıca okul öncesi eğitim program kitabına çocukları tanıma ve değerlendirmede kullanılabilecek alternatif, dinamik değerlendirme yöntemleri ile ilgili bilgi içerikli yazılar ve uygulama örnekleri eklenmelidir.

Özetle söylemek gerekirse araştırma sonucunda okul öncesi öğretmenlerinin, çocukları değerlendirme ve tanıma tekniklerine yönelik bilgi düzeylerinin yetersiz olmakla beraber kullandıkları yöntem ve araçlarının fazlasıyla sınırlı olduğu saptanmıştır. Ayrıca öğretmenlerin günümüzde kullanılan, oyun temelli değerlendirme, dinamik değerlendirme gibi alternatif değerlendirme yöntemlerini duymadıkları saptanmıştır. Bu bulgular ışığında öğretmenlerin, eğitim süreci boyunca farklı değerlendirme yöntemlerini kullanmaya teşvik edilmesi gerekliliği, okul öncesi öğretmen adaylarının öğretmenlik uygulaması gibi derslerde en az bir çocukla değerlendirme sürecini deneyimlemesi gerektiği önerilmektedir. Ayrıca hâlihazırda öğretmenlik görevi yapan okul öncesi öğretmenlerine de çocukları tanıma ve değerlendirmeye yönelik hizmet içi eğitim çalışmalarının yapılması önerilmektedir. Özellikle gelişimsel tarama araçları, sistematik gözlem, oyun temelli değerlendirme ve portfolyo kullanımı gibi temel konularda öğretmenlerin eksiklerinin giderilmesi okul öncesi sınıflarda değerlendirmelerin yapılmasını ve bu yolla eğitim kalitesinin artacağı düşünülmektedir. $\mathrm{Bu}$ araştırma ortaya koyduğu önemli bulgulara rağmen bazı sınırlılıklar taşımaktadır. Çevrimiçi veri toplama yöntemleri ile nicel bulguların bir kısmı toplanmıştır. Bu nedenle öğretmenlerin sorulara cevap verirken farklı kaynaklardan yararlanmış olabileceği düşünülmektedir. Gelecekte yapılacak araştırmaların öğretmenlerin bilgi düzeyini belirlerken sınav güvenliği konusunda önlem almaları önerilmektedir. 
Okul Öncesi Öğretmenlerinin Çocukları Değerlendirmedeki ...

\section{Yazarların Beyanı}

Araştırmacıların katkı oranı beyanı: Verilerin toplanması, analiz edilmesi ve makalenin yazım aşamasında bütün araştırmacılar birlikte çalışmıştır.

Etik Kurul Kararı: Aydın Adnan Menderes Üniversitesi, Eğitim Araştırmaları Etik Kurulu 11.12.2018 tarihli 2018/12 sayılı kararı.

Çatışma beyanı: Araştırma sürecinde herhangi bir kişi ya da kurumla çıkar çatışması yaşanmamıştır.

Destek ve teşekkür: Bu çalışmaya desteğini sunan katılımcı okul öncesi öğretmenlerine ve araştırmamıza katkılarından dolayı hakemlere teşekkürlerimizi sunarız.

\section{Kaynaklar}

Aktepe, V. (2005). Eğitimde bireyi tanımanın önemi. Gazi Üniversitesi Kırşehir Eğitim Fakültesi Dergisi, 6(2), 1524.

Banerjee, R. ve Luckner, J. L. (2013). Assesment practices and training needs of early childhood professionals. Journal of Early Childhood Teacher Education, 34(3), 231-248.

Bloom, B. S. (Ed.). (1979). Taxonomy of educational objectives: The classification of educational goals book 1 cognitive domain. Michigan: Longman Green and Co LTD.

Bredekamp, S. (2015). Erken çocukluk eğitiminde etkili uygulamalar [Effective Practices in Early Childhood Education (2nd edition)] (H. Z. İnan ve T. İnan, Çev.). Ankara: Nobel Yayıncılık.

Bredekamp, S. ve Rosegrant, T. (1992). Reaching potentials: Appropriate curriculum and assessment for young children. Volume 1. Washington: National Association for the Education of Young Children.

Brown, J. ve Rolfe, S. A. (2005). Use of child development assessment in early childhood education: Early childhood practitioner and student attitudes toward formal and informal testing. Early Child Development and Care, 175(3), 193-202.

Burgazlı Osanmaz, M. S. B. ve Akman, B. (2018). Okul öncesi öğretmenlerinin eğitim programları içerisinde kullandıkları planlardaki değerlendirme boyutlarının incelemesi. Dinçer, S. (Ed.), Değişen dünyada eğitim (s. 81-94) içinde. Ankara: Pegem Akademi Yayıncılık.

Büyüköztürk, Ş., Çakmak, E. K., Akgün, Ö. E., Karadeniz, Ş. ve Demirel, F. (2016). Bilimsel araştırma yöntemleri (21. bs.). Ankara: Pegem Akademi Yayıncllı.

Creswell, J. W. (2003). Research design: Qualitative, quantitative, and mixed method approaches. London: Sage Publications, Inc.

Creswell, J. W. (2009). Mapping the field of mixed methods research. Journal of Mixed Methods Research, 3(2), 95-108.

Denzin, N. K. ve Lincoln, Y. S. (1998). Strategies of qualitative inquiry. Los Angeles, London, New Delhi, Singapore: SAGE Publications.

Fantuzzo, J., Tighe, E. ve Childs, S. (2000). Family Involvement Questionnaire: A multivariate assessment of family participation in early childhood education. Journal of educational psychology, 92(2), 367-376.

Furat, E., Usta Sayın, H. G. ve Uluman, M. (2012). Problem experienced by preschool teachers while appyling assesment and evalution methods. Procedia Social and Behavioral Sciences, 46, 3936-3941.

Gullo, D. F. (2005). Understanding assessment and evaluation in early childhood education. NY: Teachers College. 
Hatch, J. A. (2002). Doing qualitative research in education settings. New York: State University of New York Press.

Hopkins, W. G. (2014). A new view of statistics. 05 Aralık 2015 tarihinde www.https://complementarytraining.net/wp-content/uploads/2013/10/Will-Hopkins-A-New-View-ofStatistics.pdf adresinden erişildi.

Howard, V. F., Williams, B. F. ve Lepper, C. (2010). Very young children with special needs: A foundation for educators, families, and service providers. Upper Saddle River, NJ: Prentice- Pearson.

Işıkoğlu Erdoğan, N. ve Canbeldek, M. (2017). Erken çocukluk eğitiminde ölçme ve değerlendirme. Abant İzzet Baysal Üniversitesi Ĕ̆itim Fakültesi Dergisi, 17(3), 1306-1327.

Karaağaçlı, M. (2002). Değerlendirme süreci. Mesleki eğitim ve teknoloji eğitimde özel öğretim yöntemleri. Ankara: Nobel Yayınları.

Karasar, N. (2011). Bilimsel araştırma yöntemi (11. bs.). Ankara: Nobel Yayınevi.

Kaya, İ. (2018). Examination of preschool teachers' opinion on alternative assessment. Universal Journal of Educational Research, 6(10), 2294-2299.

Kwi-Ok N. ve Jung-In K. (2011). Child assessment in early childhood education and care settings in South Korea. Asian Social Science, 7(6), 66-78.

Lidz, C. S. (2002). Mediated Learning Experience (MLE) as a basis for alternative approach to assesment. School Psychology International, 23(1), 68-84.

McAfee, O. ve Leong, D. J. (2012). Erken çocukluk döneminde gelişim ve öğrenmenin değerlendirilmesi ve desteklenmesi (B. Ekinci, Çev. Ed.). Ankara: Nobel.

McAfee, O., Leong, D. J. ve Bodrova, E. (2004). Basics of assessment: A primer for early childhood educators. Washington, DC: National Association for the Education of Young Children.

Meisels, S. J. ve Atkins-Burnett, S. (2000). The elements of early childhood assessment. J. P. Shonkoff, S. J. Meisels ve E. F. Zigler, (Ed.), Handbook of early childhood intervention (s. 231-257) içinde. Cambridge: Cambridge University Press.

Milli Eğitim Bakanlığı. (2013). Okul öncesi eğitim programı. Ankara: Devlet Kitapları Basım Evi.

Nah, K. ve Kwak, J. (2011). Child assesment in early childhood education and care settings in South Korea. Asian Social Science, 7(6), 66-78.

Önder, A. (Ed.). (2016). Okul öncesi dönemde çocukları değerlendirme ve tanıma teknikleri. Ankara: Pegem Akademi Yayıncilik.

Pyle, A. ve DeLuca, C. (2017). Assessment in play-based kindergarten classrooms: An empirical study of teacher perspectives and practices. The Journal of Educational Research, 110(5), 457-466.

Riley, K., Miller, G. E. ve Sorenson, C. (2016). Early childhood authentic and performance-based assessment. A. Garro (Ed.), Early childhood assessment in school and clinical child psychology (s. 95-117) içinde. New York: Springer.

Seidman, I. (2006). Interviewing as qualitative research: A guide for researchers in education and the social sciences. New York and London: Teachers College Press. 
Shepard, L. A., Kagan, S. L. ve Wurtz, E. (1998). Principles and recommendations for early childhood assessments. Washington, DC.: National Education Goals Panel.

Snow, C. E. ve Van Hemel, S. B. (2008). Early childhood assessment: Why, what, and how. Washington D.C.: The National Academies Press.

Tagay, Ö. (2016). Okul öncesi eğitimde çocuğu tanımanın önemi. Önder, A. (Ed.), Okul öncesi dönemde çocukları değerlendirme ve tanıma teknikleri (s. 2-8) içinde. Ankara: Pegem Akademi Yayıncılık.

Taner, G. (2005). Bireyi tanıma tekniklerinin okul öncesi eğitim kurumlarında uygulanmasına ilişkin öğretmen görüşlerinin incelenmesi (Yayımlanmamış yüksek lisans tezi). Selçuk Üniversitesi, Sosyal Bilimler Enstitüsü, Konya.

Tashakkori, A. ve Creswell, J. W. (2007). The new era of mixed methods. Journal of Mixed Methods Research, $1(1), 3-7$.

Turupçu, A. (2014). Observation as an assessment tool in early childhood education: A phenomenological case study of theacher views and practices (Yayımlanmamış doktora tezi). Orta Doğu Teknik Üniversitesi, Ankara.

Yıldırım, A. ve Şimşek, H. (2000). Sosyal bilimlerde nitel araştırma yöntemleri. Ankara: Seçkin Yayınevi.

Yılmaz, H. ve Zembat, R. (2019). Okul öncesi öğretmen adaylarının duygusal zeka düzeyleri ile üniversite yaşamına uyumları arasındaki ilişkinin incelenmesi. Mehmet Akif Ersoy Üniversitesi Eğitim Fakültesi Dergisi, (52), 118-136.

Yılmaz Topuz, G. ve Erbil Kaya, Ö. M. (2016). Okul öncesi eğitim öğretmenlerinin çocukları tanıma ve değerlendirme amaçlı yapılan çalışmalara ilişkin görüşleri. Anadolu Üniversitesi Ĕ̆gitim Bilimleri Enstitüsü Dergisi, 6(1), 27-62. 


\section{EXTENDED ABSTRACT}

\section{Introduction}

Child assessment plays a critical role in planning and delivering quality services to children and their families (Banerjee and Luckner, 2013). To achieve the expected benefit from the assessment, teachers should attempt to develop their knowledge and skills about child assessment with sufficient experience to use the assessment tools (Önder, 2016). Examining preschool teachers' knowledge and competence levels about child assessment would be useful to improve the quality of early childhood services and children's learning and development. Therefore, this research aims to determine the tools used by preschool teachers in assessing children's development and the teachers' level of competency in child assessment.

\section{Method}

As a mixed-method study, both quantitative and qualitative data collection tools were employed within this research. Five hundred eighteen preschool teachers working across Turkey were the participants of the quantitative data. Researchers developed The Child Evaluation and Assessment Knowledge Test (RAKTC) to collect quantitative data. The reliability and validity of the test were ensured. A total of ten volunteer teachers ( 5 chosen among teachers received the highest scores from the test, and five teachers selected from among the received lowest scores) participated in the qualitative dimension of the research. Semi-structured interviews with ten participant teachers were for qualitative data collection. Again, samples of the child assessment tools used by the teachers were collected as documents. Teaches test scores, semi-structured interviews, and document collection provide evidence in the data triangulation.

\section{Results}

Quantitative findings of the research suggested that $14.86 \%$ of the participant preschool teachers received low scores, and $64.86 \%$ received average scores; only $20.27 \%$ received high scores in the RAKTC test. This result revealed that knowledge and competence levels of the participant teachers regarding child assessment and evaluation were at moderate levels. Additionally, the content analyzes of teacher interviews revealed three important themes, including 1) Why am I assessing? 2) What am I assessing? 3) How do I assess and document the children's' learning and development? Qualitative results indicated that teachers with high level of competence assessed children to "monitor the developmental process", "prepare better daily plans", "identify children with special needs", "present reports while communicating with parents and administrators" and "give children opportunities to know themselves better". On the other hand, participant teachers with the low level of competence assessed children to "share information with families", "identify children's interests", "determine developmental domains that needed to be supported in children." Again, the teachers with high competency assessed the cognitive, psychomotor, language development, and self-care skills of children. On the other hand, teachers with low competency stated that they focused on children's social and emotional development more than cognitive development. When the teachers with high or low competence levels compared, there were differences in child assessment tools that they used in their classrooms. Teachers with high competence levels asserted that they frequently used "the Ministry of National Education's program gains and indicators" as an assessment tool. Specifically, they claimed that the acquisition-indicator control lists were beneficial for the child assessment. On the other hand, teachers with low competence levels stated that they commonly method used observation and portfolio techniques for child assessment. They reported that observing children at learning centers and their social relationships were the widely used assessment tools for them.

\section{Conclusion}

Considering this study's findings, participant preschool teachers' competence levels about child assessment were ranged from medium to low. Unfortunately, the results indicated that participants teachers conducted child assessment without having sufficient knowledge about assessment and evaluation (Snow and Van Hemel, 2008; Zembat and Y1lmaz, 2019). Therefore, it is necessary to have more in-service training about child assessment and evaluation. Specifically, these trainings should more focus on the value of the child 
assessment and different types of assessment tools. Moreover, all participant teachers rarely mentioned about using standardized tests and alternative assessment methods to assess children's development and learning. These types of assessment tools are not commonly used by early childhood education teachers (Yilmaz Topuz, ve Erbil Kaya, 2016). In service trainings focused on standard tests, dynamic and played based assessment tools will be beneficial for these teachers. 